\title{
Development of new polymorphic microsatellite markers in topmouth culter (Culter alburnus) and determination of their applicability in Culter mongolicus
}

\author{
P.-Z. Qi' ${ }^{1}$, C.-X. Xie ${ }^{1}$, B.-Y. Guo ${ }^{2}$, C.-W. Wu' ${ }^{2}$, S.-M. Lu' ${ }^{1}$ and Y.-J. Duan ${ }^{1}$ \\ ${ }^{1}$ College of Fisheries, Huazhong Agricultural University, \\ Wuhan, Hubei, P.R. China \\ ${ }^{2}$ Marine Science College, Zhejiang Ocean University, \\ National Engineering Research Center of Marine Facilities Aquaculture, \\ Zhoushan, Zhejiang, P.R. China \\ Corresponding author: C.-X. Xie \\ E-mail: xiecongxin@mail.hzau.edu.cn
}

Genet. Mol. Res. 12 (2): 1761-1765 (2013)

Received July 11, 2012

Accepted March 7, 2013

Published May 21, 2013

DOI http://dx.doi.org/10.4238/2013.May.21.7

\begin{abstract}
Fifteen new polymorphic microsatellite markers were developed for Culter alburnus. In 32 individuals representing a wild population of the Danjiangkou Reservoir, Hubei, China, the number of alleles at these loci varied between 2 and 10, with an average of 5.5. The average observed and expected heterozygosities were 0.664 and 0.681 , respectively. The polymorphism information content of 11 loci was more than 0.5 whereas that of the other 4 loci was less than 0.5 but more than 0.25 . In addition, the genomes of $30 \mathrm{C}$. mongolicus individuals were successfully amplified with these primer pairs, indicating that the primer pairs were applicable for the related species, C. mongolicus.
\end{abstract}

Key words: Culter alburnus; Culter mongolicus; Microsatellite; Cross-species amplification 


\section{INTRODUCTION}

Topmouth culter (Culter alburnus Basilewsky) belonging to the family Cyprinidae widely inhabits major rivers, lakes, and reservoirs of China (Luo and Chen, 1998). Among the various species of the genus Culter, topmouth culter has the longest body. For a long time, $C$. alburnus, Trachidermus fasciatus, Yellow River carp, and Songhua River salmon have been considered the four most famous fresh water fish species because of their delicious taste and tender meat (Wang, 2007). As one of the most important commercial freshwater fish species in China, the annual culturing yield of $C$. alburnus has continuously increased over the past decades to approximately 1500 tons in recent years. Previous studies have found that C. alburnus lays two types of egg: fish living in rivers lay floating eggs and those living in lakes and reservoirs lay sticky eggs (Cheng, 2006). However, many questions remain unclear, including the reasons for laying different types of eggs. We hypothesized that the genomes of fish inhabiting different environments are differentiated.

Microsatellites or simple sequence repeats (SSRs) have been widely used in deciphering population structures as well as determining parentage and kinship (O'Connell and Wright, 1997), constructing linkage maps, further understanding the genetic bases of important traits, and selecting elite varieties of diverse fish species (Brown et al., 2007; Guo et al., 2009; Wang et al., 2011). A few microsatellites are available for C. alburnus (Chen et al., 2009; Li et al., 2010), but unfortunately, the number of SSRs available for this species is limited. In this study, we identified 15 new SSR markers for C. alburnus and determined their applicability in C. mongolicus.

\section{MATERIAL AND METHODS}

Genomic DNA was isolated from the dorsal fin using the traditional proteinase K digestion and phenol-chloroform extraction method in combination with RNase treatment. The DNA was digested with TruII into 400-1000-bp fragments, which were ligated with a TruII adapter. The fragments were hybridized with a biotin- $(\mathrm{CA})_{12}$ probe and bound to streptavidin-coated beads (Dynal Biotech, Oslo, Norway). The eluted strands were amplified with adapter-specific primers, inserted into the pMD18-T vector (TaKaRa), and transformed into DH5 $\alpha$ competent cells. Recombinant clones were screened for SSR-containing inserts, and positive clones were sequenced with the T7 primer using an ABI PRISM 3730 automated sequencer. After removing the vector sequences by comparison to vector sequences deposited in the GenBank (searched by BLAST on the NCBI website), the trimmed sequences were screened for microsatellites using SSR Hunter. Primers were designed on the basis of the identified SSRs and appropriate flanking regions by using PRIMER 3 (Rozen and Skaletsky, 2000). Using a subset of templates (5 fishes), the annealing temperature of each pair of primers was optimized.

The polymorphism of each microsatellite was assayed by $8 \%$ non-denaturing polyacrylamide gel electrophoresis with 32 specimens of C. alburnus, representing the wild population of the Danjiangkou Reservoir, and 30 individuals of $C$. mongolicus. The number of alleles $\left(N_{\mathrm{A}}\right)$, observed heterozygosity $\left(H_{\mathrm{O}}\right)$, and expected heterozygosity $\left(H_{\mathrm{E}}\right)$ were calculated with POPGENE 1.32 (Yeh and Boyle, 1997). MICRO-CHECKER (Van Oosterhout et al., 2004) was used to infer the most probable technical cause of Hardy-Weinberg equilibrium (HWE) departures, and the significance was adjusted using the sequential Bonferroni's correction (Rice, 1989). The polymorphism information content (PIC) was calculated by the Botstein method: 


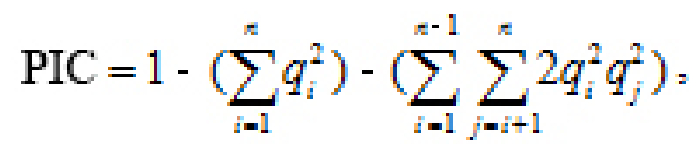

where $q_{i}$ and $q_{j}$ represent the allele frequencies of the $i^{\text {th }}$ and $j^{\text {th }}$ alleles, respectively, and $n$ is the number of alleles (Botstein et al., 1980).

\section{RESULTS AND DISCUSSION}

In all, 58 sequences containing microsatellites were obtained in this study. Thirty-five sequences contained appropriate flanking regions, and from these sequences, 35 microsatellite markers (35 pairs of primers) were designed. The genomes of 32 C. alburnus individuals (representing the wild population of the Danjiangkou Reservoir) were successively amplified with 24 designed primer pairs. Polymorphism was detected in C. alburnus with 15 primer pairs (Table 1) by using the optimized annealing temperatures listed in Table 1.

Table 1. Characterization of 15 polymorphic microsatellite markers in Culter alburnus.

\begin{tabular}{|c|c|c|c|c|c|}
\hline Locus & Accession No. & Primer sequence $\left(5^{\prime}-3^{\prime}\right)$ & Repeat motif & $\mathrm{Ta}\left({ }^{\circ} \mathrm{C}\right)$ & $\mathrm{S}(\mathrm{bp})$ \\
\hline$\overline{Q Z 194}$ & JQ965647 & $\begin{array}{l}\text { F: CCCATCCAAGTTGGTGTGTA } \\
\text { R: TCAGCAGCTCAGAAATCGAGAA }\end{array}$ & $(\mathrm{CA})_{45}$ & 62 & $198-256$ \\
\hline QZ91 & JQ965648 & $\begin{array}{l}\text { F: CTCCTGCATTTTTTTCCACTTGC } \\
\text { R: TTCTTAGAGAAGAGGCAGCGG }\end{array}$ & $(\mathrm{TC})_{10}$ & 59 & $285-335$ \\
\hline QZ126 & JQ965649 & $\begin{array}{l}\text { F: CATTTTCAGTTCACAGTCCAAGA } \\
\text { R: CATTACAGACGCATGAGCAACA }\end{array}$ & $(\mathrm{GT})_{12} \mathrm{GA}(\mathrm{GT})_{21}$ & 63 & 249-301 \\
\hline QZ150 & JQ965650 & $\begin{array}{l}\text { F: TACCACTGGAACCACAGTCTCCTG } \\
\text { R: AATGACATCGCTCTCCTGCAA }\end{array}$ & $(\mathrm{TG})_{15}$ & 65 & $258-296$ \\
\hline QZ188 & JQ965651 & $\begin{array}{l}\text { F: CACAAACACATTCACAATTCTGGG } \\
\text { R: GTCAATCAAAAACACTGACATTT }\end{array}$ & $(\mathrm{GT})_{7}$ & 64 & $259-281$ \\
\hline QZ68 & JQ965652 & $\begin{array}{l}\text { F: GTGATCATGAAAACTGACTGAAC } \\
\text { R: CGAGCGTGAAGATGTACAGAATGA }\end{array}$ & $(\mathrm{TG})_{10} \mathrm{G}(\mathrm{TA})_{5}$ & 64 & $218-256$ \\
\hline$Q Z 73$ & JQ965653 & $\begin{array}{l}\text { F: CTGAAGGTTATATTTGGGGTGAG } \\
\text { R: TCAGCAGATAAAGTAGAGAGGTCA }\end{array}$ & $(\mathrm{TG})_{10} \ldots(\mathrm{AG})_{11}$ & 65 & $224-318$ \\
\hline QZ133 & JQ965654 & $\begin{array}{l}\text { F: TAAAACGAGGGAGGCATGAAGA } \\
\text { R: GTATGCGATATACGGTCATTCACC }\end{array}$ & $(\mathrm{GT})_{17}$ & 62 & $285-309$ \\
\hline QZ175 & QZ175 & $\begin{array}{l}\text { F: CACCGACGGCACAGACAT } \\
\text { R: TGTTACCGCTGAAAACACACA }\end{array}$ & $(\mathrm{TA})_{5} \ldots(\mathrm{TG})_{33} \ldots(\mathrm{AC})_{5} \mathrm{AT}(\mathrm{AC})_{9}$ & 67 & $255-367$ \\
\hline QZ214 & JQ965656 & $\begin{array}{l}\text { F: AGCGGTTGAGGAGCTGTATTA } \\
\text { R: TCCCTGAATGTTGTAAGACCA }\end{array}$ & $(\mathrm{CA})_{7}$ & 59 & $308-330$ \\
\hline QZ11 & JQ965657 & $\begin{array}{l}\text { F: TTCATTACGGTCGAACCACC } \\
\text { R: ATGCGGATGGTTCCTGGATAA }\end{array}$ & $(\mathrm{GT})_{7} \mathrm{GC}(\mathrm{GT})_{9}$ & 65 & $186-212$ \\
\hline QZ119 & JQ965658 & $\begin{array}{l}\text { F: GCAAAGAGGGGTTCAGTGAAT } \\
\text { R: TGATCTGCTCTGATGCTGGAT }\end{array}$ & $(\mathrm{GT})_{6}$ & 65 & $174-228$ \\
\hline QZ204 & JQ965659 & $\begin{array}{l}\text { F: TCGATCAGACTGTCCATGGGT } \\
\text { R: TGATTGGCAACAGCTGGAGA }\end{array}$ & $(\mathrm{AC})_{10}$ & 65 & $128-225$ \\
\hline QZ94 & JQ965660 & $\begin{array}{l}\text { F: TCACCCGTGGGTCTCTGAAAT } \\
\text { R: AGTGCTCTAAGCTGAGCGGA }\end{array}$ & $(\mathrm{CA})_{51}$ & 60 & $224-316$ \\
\hline QZ19 & JQ965661 & $\begin{array}{l}\text { F: CAGGCTCCATATAATGACAATGA } \\
\text { R: TGACACGTGTTTGGGTAATGACTG }\end{array}$ & $(\mathrm{AC})_{11} \ldots(\mathrm{CT})_{12}$ & 63 & $234-286$ \\
\hline
\end{tabular}

$\mathrm{Ta}=$ annealing temperature; $\mathrm{S}=$ allele size range.

The $N_{\mathrm{A}}$ at the 15 polymorphic microsatellite loci ranged from 2 to 10 with an average of 5.5. The values of $H_{\mathrm{O}}$ and $H_{\mathrm{E}}$ ranged from 0.418 to 0.913 (average of 0.664 ) and from 0.457 to 0.912 (average of 0.681), respectively (Table 2). Significant deviation from HWE was observed 
at $Q Z 91, Q Z 188$, and $Q Z 11$. No significant linkage disequilibrium was found among the 15 polymorphic loci $(\mathrm{P}<0.003)$. The PIC of 11 of the loci was more than 0.5 , and the PIC of the remaining 4 loci (QZ91, QZ133, QZ11, and QZ119) was less than 0.5 but more than 0.25 .

\begin{tabular}{|c|c|c|c|c|c|c|c|c|}
\hline \multirow[t]{2}{*}{$\begin{array}{l}\text { Locus } \\
\end{array}$} & \multicolumn{4}{|c|}{ Culter alburnus } & \multicolumn{4}{|c|}{ Culter mongolicus } \\
\hline & $N_{\mathrm{A}}$ & $H_{\mathrm{O}}$ & $H_{\mathrm{E}}$ & PIC & $N_{\mathrm{A}}$ & $H_{\mathrm{o}}$ & $H_{\mathrm{E}}$ & PIC \\
\hline$\overline{Q Z 194}$ & 6 & 0.685 & 0.661 & 0.682 & 8 & 0.688 & 0.747 & 0.621 \\
\hline QZ91 & 4 & 0.563 & 0.628 & $0.265^{*}$ & 7 & 0.478 & 0.546 & 0.598 \\
\hline QZ126 & 9 & 0.897 & 0.912 & 0.813 & 6 & 0.944 & 0.617 & 0.527 \\
\hline QZ150 & 7 & 0.732 & 0.748 & 0.714 & 5 & 0.378 & 0.428 & 0.395 \\
\hline QZ188 & 3 & 0.431 & 0.485 & $0.546^{*}$ & 5 & 0.673 & 0.735 & 0.564 \\
\hline QZ68 & 4 & 0.574 & 0.561 & 0.615 & & & & \\
\hline$Q Z 73$ & 9 & 0.831 & 0.858 & 0.735 & 8 & 0.768 & 0.835 & 0.724 \\
\hline QZ133 & 3 & 0.643 & 0.677 & 0.425 & 4 & 0.482 & 0.568 & 0.576 \\
\hline QZ175 & 8 & 0.798 & 0.763 & 0.675 & 6 & 0.845 & 0.728 & 0.735 \\
\hline QZ214 & 3 & 0.418 & 0.457 & 0.586 & & & & \\
\hline QZ11 & 2 & 0.513 & 0.564 & $0.328 *$ & & & & \\
\hline QZ119 & 2 & 0.485 & 0.474 & 0.352 & 3 & 0.375 & 0.476 & $0.654^{*}$ \\
\hline QZ204 & 10 & 0.913 & 0.908 & 0.885 & 6 & 0.875 & 0.748 & 0.824 \\
\hline QZ94 & 8 & 0.846 & 0.877 & 0.713 & 5 & 0.568 & 0.497 & 0.726 \\
\hline QZ19 & 5 & 0.624 & 0.643 & 0.617 & 6 & 0.673 & 0.728 & 0.619 \\
\hline
\end{tabular}

$N_{\mathrm{A}}=$ number of alleles; $H_{\mathrm{O}}=$ observed heterozygosity; $H_{\mathrm{E}}=$ expected heterozygosity; PIC = polymorphic information content. *Deviation from Hardy-Weinberg equilibrium $(\mathrm{P}<0.03)$ after Bonferroni's correction.

The genomes of $30 \mathrm{C}$. mongolicus individuals were successively amplified with the 15 primer pairs that detected polymorphisms in C. alburnus (Table 2). The number of alleles per loci ranged from 3 to 8 (average of 5.8). The value of $H_{\mathrm{E}}$ ranged from 0.428 to 0.835 (average of 0.646), and the value of $H_{\mathrm{o}}$ varied between 0.375 and 0.944 (average of 0.638 ). The microsatellites developed in this study are applicable for assessing the genetic diversity and genetic structure of both C. alburnus and C. mongolicus, and they facilitate the identification of C. alburnus that lay different types of eggs.

\section{ACKNOWLEDGMENTS}

Research supported by the State Science and Technology Support Program of China (\#2012BAD25B06).

\section{REFERENCES}

Botstein D, White RL, Skolnick M and Davis RW (1980). Construction of a genetic linkage map in man using restriction fragment length polymorphisms. Am. J. Hum. Genet. 32: 314-331.

Brown B, Wang HP, Li L, Givens C, et al. (2007). Yellow perch strain evaluation I: Genetic variance of six broodstock populations. Aquaculture 271: 142-151.

Chen SQ, Liu QG, Ren SJ and Gong XL (2009). Polymorphic microsatellite loci isolated from the topmouth culter (Culter alburnus Basilewsky). Conserv. Gene Resour. 1: 337-339.

Cheng P (2006). Effect of Starvation and Refeeding on the Activity of Digestive Enzymes, Feeding and Growth, Biochemical Composition of Erythroculter Ilishaeformis Juvenile. Master's thesis, Huazhong Agricultural University, Huazhong.

Guo BY, Xie CX, Shan L, Zhang Y, et al. (2009). Development and characterization of 16 polymorphic microsatellite loci in the Tibet endemic fish Glyptosternum maculatum. Mol. Ecol. Resour. 9: 380-382. 
Li Y, Truc T and Wang WM (2010). Development of polymorphic microsatellite markers in topmouth culter (Culter alburnus). Conserv. Gene. Resour. 2: 43-46.

Luo Y and Chen Y (1998). Cultrinae. In: Fauna Sinica. Osteichthyes. Cypriniformes II (Chen YY, Chu XL, Luo YL, Chen YR, et al, eds.). Science Press, Beijing, 112-207.

O’Connell M and Wright M (1997). Microsatellite DNA in fishes. Rev. Fish Biol. Fisher. 7: 331-363.

Rice WR (1989). Analyzing tables of statistical tests. Evolution 43: 223-225.

Rozen S and Skaletsky HJ (2000). Primer 3 on the WWW for General Users and for Biologist Programmers. In: Bioinformatics Methods and Protocols (Methods in Molecular Biology) (Krawetz S and Misener S, eds.). Humana Press, Totowa, 365-386.

Van Oosterhout C, Hutchinson WF, Wills DPM and Shipley P (2004). MICRO-CHECKER: software for identifying and correcting genotyping errors in microsatellite data. Mol. Ecol. Notes 4: 535-538.

Wang W (2007). Study on Population Genetic Diversity of Culter Alburnus and Phylogeny of Cultrinae. Doctoral thesis, East China Normal University, Shanghai.

Wang CM, Bai ZY, He XP, Lin G, et al. (2011). A high-resolution linkage map for comparative genome analysis and QTL fine mapping in Asian seabass, Lates calcarifer. BMC Genomics 12: 174.

Yeh FC and Boyle TJB (1997). Population genetic analysis of co-dominant and dominant markers and quantitative traits. Belg. J. Bot. 129: 157. 